University of New York-Binghamton) challenged the assumption that immigrants' political behavior was shaped by their experiences as a preindustrial workforce in Italy. On the contrary, the militance of Italian immigrants in Paterson, New Jersey developed in the transition from domestic to industrial production in the textile districts of Italy. In the transformation from worker-peasants to proletarians, workers developed a working-class identity. Their cultural heritage, which "valued anarchism, socialism, and organized unionism" and was intent on the emancipation of labor, informed their activity in Paterson. Donna R. Gabaccia (University of North Carolina-Charlotte) argued for research into political, as distinguished from labor, migration. The politics of Italian political migrants followed the history of reform and revolution in Italy: nationalists, followed by anarchists, socialists, and under fascism, communists. This paralleled a decline in upper- and middle-class migration so that by World War I political migrants came to "resemble labor migrants." Political migrants differed from labor migrants in choosing European destinations from where they could influence Italian politics. Gabaccia concluded with a call for further study of the connections between political migration and national migration policy.

\title{
American Historical Association: Women's Labor History
}

\author{
Kali A.K. Israel \\ University of Cincinnati
}

The 1992 meeting of the American Historical Association was notably lacking in panels dedicated to labor history, although many papers dealing with aspects of working-class political or cultural activity were included. A high proportion were concerned with the history of women workers and-the relationships between gender, work, class identity, and social change.

A session on "Narrative Authority and Women's Lives in Late 19th-Early 20th Century Britain: Middle-Class Women's Representations of Working-Class Women," chaired by Ian C. Fletcher, analyzed the interactions of middle- and working-class women. Kali Israel's "Working-Class Women as Selves and Others: Trade Unionism and Self-Creation in the Life of Emilia Dilke," and Polly Beals's "Imagining Women and Socialist Alternatives in Fabian Texts," considered the ways in which middle-class women engaged in struggles for meaningful public activity and political roles deployed representations of working-class women in their texts. Israel argued that Dilke's rhetorical strategies, as president of the Women's Trade Union League, emphasized that women workers were both like and unlike middle-class women, possessing their own perceptions, voices, and desires, but not completely "Other." Beals, however, found that Fabian women's portrayals of the working-class women of Lambeth in the 1920s for Round About a Pound a 
Week tended to emphasize the latter's domesticity, passivity, and isolation, and to lack an awareness of the working-class community. Both Israel and Beals argued that middle-class women's representations of working-class women involve complex dynamics of identification, projection, and distancing; Beals's study particularly suggests the importance of reading even the most "empirical" and wellintentioned middle-class texts as evidence of unequal struggles between workingclass voices and middle-class feminists" own textual and political needs. Angela Woolacott's "Engendering Professional Authority: Welfare Supervisors, Women Police and Patrols. and the Working-Class Woman as Subject" also argued that women police and welfare workers during World War I used their ability to speak for and about working-class women to forge a professional discourse that legitimized their own presence in the work force and the public sphere. These newlyprofessionalized groups of women with authority over other women represented working women as needing control, and drew upon older languages of bourgeois women's moral authority as well as the rhetorics of professional policing and social work, in attempts to substantiate their own claims to salaried work, authority, and participation in national public life. In all these papers, however, the authors emphasized that working-class women were not passive objects of middleclass constructors of meaning-systems.

A panel chaired by Sue Levine entitled "Revisioning the Political: How Does Gender Structure Class?" dealt with the relationships between class and gender identities more explicitly, including analyses of both consciousness and material conditions. Anna Clark presented "Domesticity and Chartism: Language and Gender in the Makings of a Working Class" (a longer version has since appeared in The Journal of British Studies 31 [January 1992]). Clark examined the crucial roie of ideas about domesticity and gender arrangements in the formation of a positive national working-class political identity through the elaboration and consolidation of distinctive models of sexual and gender behavior. Clark's study drew upon extensive research in Glasgow, London, and Lancashire, and suggested that Chartist attempts to grapple with the "sexual crisis" of working-class culture foundered on the Chartists" difficulties in reconciling their wishes for a workingclass femininity which was both activist, economically productive, and thoroughly domestic and morally respectable, and a working-class masculinity which was simultaneously public and private, political and domestic, independent and communitarian. More fundamentally, Clark suggests that the Chartists' commitment to male dominance both underlay and undercut their ability to create a rhetoric of working-class political identity.

In a different national and temporal context, Pamela Radcliff's paper, "Elite Women Workers and Class Consciousness: The Spanish Cigarette Makers, 1890 $1930, "$ considered the complexities of class and gender identity for a particular group of working-class women. Cigarette workers, Radcliff argues, not only have been mythologized through cultural images like that of Bizet's Carmen, which transcend their local context and celebrate the cigarette makers as independent, 
feisty, and emblematic of a regional culture, but additionally the material and social circumstances of these workers' lives fostered a multiple consciousness. Both "artisanal" and "proletarianized," both distinct among women workers and rendered symbolic of a certain form of Spanish womanhood, both gendered as women workers and representative in some contexts of Spanish workers more generally, cigarette workers were deeply conscious of the own symbolic resources at their command. Their political and labor activities drew upon varied rhetorics of religion and nationality, independence and communal identity, giving them both a flexible vocabulary of consciousness and an ambiguous status within the overall development of Spanish working-class and female politics.

Geoff Eley's commentary on Clark's and Radcliff's papers underlined the importance of such projects to the recasting of the largest historical interpretations - especially in labor history - in light of the history of gender, and called for continued studies that, like these, are anti-reductionist and sensitive to the particularities of place, rhetoric, and representation, but that remain engaged with the largest questions of local and national class formation.

\title{
North American Labor History Conference: Men, Women, and Labor: Perspectives on Gender and Labor History
}

\author{
Lisa Kannenberg, Michelle Brattain and Colleen O'Neill \\ Rutgers University
}

In a recent article in Reviews in American History. Richard Oestreicher observed that historians of women and historians of workers have much in common, "yet they remain discrete and largely separate academic tribes." Addressing the North American Labor History Conference in October 1991. Alice Kessler-Harris noted in response that "historians of women and historians of workers are sometimes the same people." Many of those people were on hand in Detroit for the conference, "Men, Women, and Labor: Perspectives on Gender and Labor History." suggesting that class and gender are not exclusive categories of analysis.

The panels explored the nexus of class and gender from a variety of angles. Conventional wisdom tends to associate gender with issues of culture, and class with the material relations of the workplace. Collectively, these papers demonstrated that the boundaries between material and cultural analysis, and gender and labor history, are not impermeable. For example, several papers examined how gender ideology shaped work environments and workplace technology. Margaret Hedstrom "s "Why Gender Matters in Office Automation. 1950-1980," suggested that ideas about women informed the design of office technology and shaped the process of office automation. Assuming that office work was routine and un- 